牛の鼓脹症と反蜀胃内性状

星 野 貞 夫

三重大学農学部, 津市 514

\title{
Foamy Bloat and Related Reticulo-Ruminal Phenomena in Cattle
}

\author{
Sadao Hoshino \\ Faculty of Agriculture, Mie University, Tsu 514
}

牛の鼓脹症は古くから知られており，栄責価の高いマ 入科牧草の草地への放牧時に発生し，死亡することも希 ではないから，草地を主体とする畜産業にとって注看過 できない障害の一つである。また，浱厚飼料多給を特徵 としているフィードゥット肥育牛にも鼓脹症は発生し, わが国の肥育牛の疾病の 3 割近くを占め, 呼吸器病と双 璧をなしている1，鼓脹症による損失は，1）急性な経過 をたどる死廃および慢性的な発症のための淘汰，2）発 症牛の生産性の低下，3）発症防止のための高栄養価牧 草の低栄養価牧草への転換，4）予防または治療のため の医療費と労力，5）発症による経営管理者の精神的肉 体的苦痛，6）鼓脹症の研究への投資などが見積られな ければならず，これらの総計は莫大な額に達するものと 思われる. しかし, 通常は 1) の及を損失として計上す るが，それでも米国の年間摃害額は 400 億円にのほり， カナダ, ニュージランド, オーストラリアなどでも相応 な損害頑が報告されている゙、.わが国でもわれわれの試 算では，肥育牛で最小に見積っても年間 10 億円は下ら ないるのと思われる ${ }^{3)}$.

鼓脹症の発生率は気象状況によっても違い, 世界の統 計はなく正確なことは分らないが，郝告されている数值 からみると蓄牛の 1\%程に発症している゙2. わが国では， 1961 1963 年の平均で発生率 19〜38\%，死亡率 1.7 $3.8 \%$ と報告されている 模なフィードロット方式の肥育が増加していることから 発症率, 死亡率とあに堌加するにしても減少していない むの之推察される.

日畜会報, $54(3) ： 153-164$

鼓脹症は発症率, 死亡率も高く，それによって被る損害 む大きいことから，これまでに多くの研究がなされてき た. 総説も多く，最近のものを揭げると COLE and BODA $(1960)^{5)}$, Hungate $(1966)^{6)}$, CLARKE and Reid $(1970)^{7)}$ $(1974)^{2)}, \operatorname{ReID} 5(1975)^{8)}$, BaRTLEY ら $(1975)^{9)}$ など で,わが国では篠崎 $(1966)^{4)}$, 星野 $(1981)^{10)}$ の総説が ある.従って本総説では，これまでの研究のすべてをか バーすることを目的とせず, CLARKE and REID ${ }^{2)}$ が総括 した研究とそれ以後の研究を中心に，特に発症因と関 連した反㽞胃内性状に力点をおいて概説することを試み た.

\section{I. 鼓脹症の分類}

鼓脹症は正常時にはあい気として排出される多量のガ スが，何らかの原因で排出不能となり，ルーメン(以下 第一胃，第二胃を含めルーメンという）飞蓄皘し，腹部 が太鼓のように膨張し，そのため呼吸困難に楩り，空息 死するるのを主徵としている、死に至らず，自然に治澺 したり，発生をくり返寸場合もある. COLE ら ${ }^{11)}$ に上れ ば，症状により次のように分類される。

1. 慢性鼓脹飼料の質に関係なく腹部膨張がみら れるもので，矮性牛帅曼性的消化器障害加腹慔炎家患。 ている牛に発生する鼓脹琼. 䬣餓時には発諚しないが, 饲料給与時には提取量により発症状況は変化する.

2. 亜急性鼓脹多汁のマメ科牧草と加濃厚飼料な ど特殊な飼養条件の下で発生する. 排烡尿が頻繁になる とか呼吸困難などの苦痛症状はみられないがルーメン 
代は最高 $57 \mathrm{mmHg}$ 李でになる。

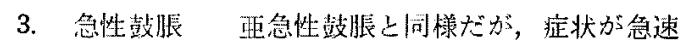
に進久, 非排洲, 呼吸困難など苦痛症状宗し，ルーメ ン压は 45〜69 $\mathrm{mmHg}$ となる。

HUNGATE ${ }^{6)}$ はルーメンガスの状況から遊離ガス鼓脹 (Free-Gas Bloat) と泡沫性鼓脤 (Frothy Bloat) とに分 けている. それ以後の総説では，この分類によるものが 多い2.7-9\}. 遊離ガス鼓脤は継発性をたは単純性鼓脹上も

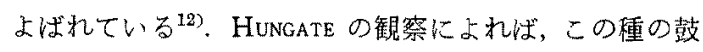
脹はーレホード種の矮性牛にみられ，あい気反射を抑制 する生理上の矢陌がある。非常に少しの飼料しか摄取し ないが，ルーメンのガス仼のため肋骨が奇形的に搪大し ていた．胃カテーテルを捙入すると噴門部で強い抵抗が

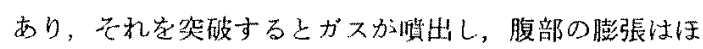
ぼ正常となり，ルーメン内容物中の微生物比顥著な差異 は認められなかった上報告している。このように遊離力゙ ス鼓脹は，胃カテーテルまたは套管針による穿刺によっ て過剩のガス它排除できる点か特徵である。しかし，泡 涑性鼓脹の場合には，そのような方法ではガスの排除が できない。

泡沫性鼓脹は，マメ科牧草鼓脹とフィードロット鼓脹 に多られ，前者は牧草 (地) 鼓脹 (Pasture Bloat), 後者 は款物鼓脹 (Grain Bloat)ともいわれる. 鼓脹症性摱性, 急性を問わず泡沫性鼓脹が一般的で，本論でもこの種の 鼓脹症を対象にしている。しかし，䈯密に遊離がス鼓脹 と泡泍性鼓脹它分けることは，両方の性質をるった鼓脹 症も観察されているから困難である5).

鼓脹症状の柽重はルーメン王の测定で判定するよう

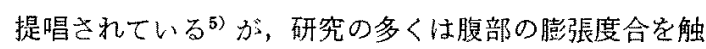
診, 視診して判定している. ELAM $5^{13)}$ は腹部の膨張の 程度加症状孛軽, 中, 重度吱脹に区別している。

\section{II. ルーメンガス排出の生理}

ルーメンには常時各種のガスが検出できる、その主な ものは，二酸化炭素とメタンであり，ともにルーメン発 酵の最終産物としてつくられる.二酸化炭素は唾液とし てルーメンに供給される重炭酸塩からも生じる.この他 に一酸化炭素，空素，酸素，硫化水素，水素など少少量 鍈出できる。これらのガスの割合は，飼料によってす変

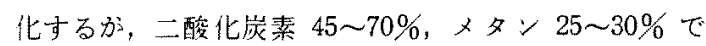
ある. MCARTHUR and MILTIMORE ${ }^{14)}$ の分析例では二酸 化炭素 $65.35 \%$ ，メタン $26.76 \%$ ，窒素 $7.00 \%$ ，酸素 $0.56 \%$, 水素 $0.18 \%$, 硫化水素 $0.01 \%$ である.

ルーメンガスはルーメン内容物に溶解している部分と 遊離ガスの状態にあるものとが存在するが，乙机らはル
一メン壁から吸収され，血液を介して脯わら，内容物と ともに下部消化管へ移動して，またはあい気反射で食道 からのいずれかの経路で排出処理される.二酸化炭素の ように溶解しやすいがスは血管系を経て排出される部分 もかなりあるが，メタンは溶解しにくく，あい気反射で

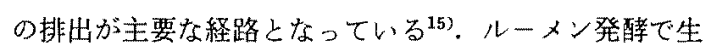
産されるメタンの割合は 15〜20\%であるが，ルーメン ガス中のそれは 25〜30\%であることは，ルーメンに放

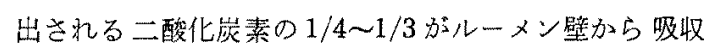
されていることを示している6゙.

ルーメンでのガス生産速度は，絶食中の牛で $0.2 l$ min. 以下 ${ }^{16,17}$, 㨨食後 $2.0 \mathrm{l} / \mathrm{min}$. が㖕測さ机てい る であり ${ }^{21)}$ ，羊では $6 \mathrm{l} / \mathrm{hr}$. という值が報告されている 往って，何らかの原因であい気反射が抑制，阻止される とたちをらガスはルーメンに蓄積し，重大な事態を招く ことになる。

あい気反射の機構は DOUGHERTY $5^{23.24}$ によって解明 され，反射は脳幹にあるあい気中枢に調節されている. あい気反射はルーメンにガスを吹き迅えで内理を高める と刺激される ${ }^{25,26)}$. 胸部背側粪走神経の電気刺激でも儿 ーメン収菂運動の增加，あい気反射の增加が 認められ 当 ${ }^{27)}$ 。通常, ルーメンのB型運動のときにあい気反射は おきるが，A 型運動の時にも，また時としてルーメン運 動なしでもおきる ${ }^{28,29}$. 噴門部周辺がルーメン内容物， 水，泡，鉱物油などのいずれで被われてもあい気反射は 阻止される ${ }^{30}$. 従って，あい気反射の誘起には噴門部周 辺がきれいにされることが必要で，ルーメン運動はとの 条件整整る役割を果している。また噴門部周辺には反 射を誘起または阻止する受容器の存在が示唆されてい כ.

ルーメンの収綰でルーメンガスは前方上部へ押しやら れ，同時に第一・二胃壁（特に羊）および前筋柱の取縮 でルーメン前部の内容物は後万八保持されるため，遊離 ガスは第二胃の背部一移動する.この時噴門が開口し， 食道へガスが送りこまれ，四因頭一食道括約筋が閉じて食 道はルーメンガスで満たされる。賀門おょび前横隔膜括

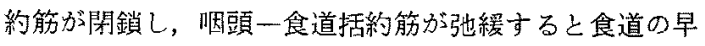
い逆ぜん動收面でガスは食道から咽頭の方向へ押しやら れる，曼咽頭括約筋の閉鎖でガスの多くは肺に入り，そ こで吸取または呼気として排出される。こうしてあい気 の半分以上が肺を経由することによってルーメンガスの フレーバーが乳汁に移行することもあるが，他方あい気

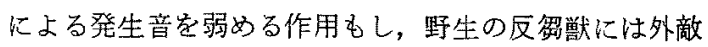
に発見されにくいという汸衛的役割定果している゙2). 
牛の鼓腿症と反䍄胃内性状

反勋食塊の昍き戻しや食道竹反射は，ガス排出への笴 与は少なく，鼓脤症との関連はない，哺釈勘物でみられ る四品叶反射も反笉動物では音通双られない，しかし，區 昍反射はユリ科の植物 Veratrum のアルカロイドで誘起 することができるので，嘔吖反射中枢が存在することを

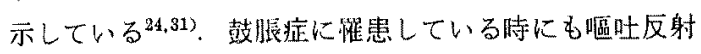
は就きない。

\section{III. 鼓脹発症時のルーメン内容物性状}

鼓脹症牛のルーメン内容物は正常牛のそれとは外見的 にも違い，牧草鼓脹の内容物は明るい粶色で，黄色が勝 っている、去固形物は少なく，消化がより進んでいる ように見える. 正常牛のルーメン内容物は色調は黑ずえ でいて，固形物が多く，液体部分は固形物之容易に分離 し，激しく振ると上層部に泡が形成されるが徐々に沈降 する. 発症牛では，一見泡はみえず，振って子表面に泡 の層が形成されないが，よくみると無数の小泡涑が内容 物中に開じ込められて䑚り，粘質な内容物のため上部へ 浮上するものは少ない。しかし，これらの小沧は徐々に 大きくなり，発醉が続くと新たな小泡が形成される゙

CLARKE and REID ${ }^{2)}$ も鼓脹を発症しやすい個体のルーメ ン内容物は泡沫を安定させる細加い粒状物が多く，掑食 後 18 時間目の内容物は発症しにくい個体のそれ上り乾 物量が少なく，粗いせえい性の食物残渣が少ないことを 観察している，しかしこれらの観察とは逆に発症牛の内 容物は乾物量が多いといら報告もある ${ }^{32}$. BARTLEY ${ }^{33)}$ は 発症牛の内容物より正常牛のそれの方がより水栐性であ るといっている.

ルーメン内容物の発症によって表われる外見上の差異 は液体部分にある泡沫によるもので，泡洙が多くなると 明るい色調になる。泡沫はルーメン液，飼料片，微生物 などの微細な粒子に被われているが，分析してみると脂

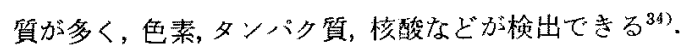
タローバーで発症した物のルーメン内容物はェタノ一ル で沈でえする粘質物が多く含まれ，この粘質物は $61 〜$ $64 \%$ タンパク質，8１4\%の糖筫，7〜10\%のリボ核酸 定含えでいだ5)。

一般にルーメン内容物は泡立つ性質があるが，普通に は泡は消えやすく，泡の量も多くない，しかし鼓脹怔で はタンパタ質样の薄膜にガスが閉し込められた泡 ${ }^{36}$ 方形 成されるため泡は強国で，消泡せず持続する.ルーメン で生産されたガスの多くは小泡となって内容物を通過 し，ルーメンの気層との界面で消泡し，ガスを放出し， ルーメンのガスキャップ（遊離ガス層）をつくる.ガス キャッブはルーメン運動で效果的に嘶門部方向从移動

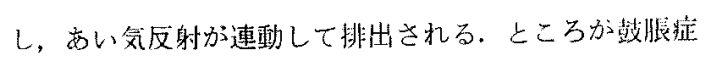
では泡が消えないために遊離がスとして放出されず，て のうえ论涞のためにルーメン内容物の签稓が增大し, 賃 閏部の清浄化が困難となるのであい気反射が抑制され， ガスの排出ができなくなる、泡立ったルーメン内㝘物 が食道に久ると少量が口腔へ吐き出されるが，同時に燕 下反射が誘発されるためガスの排出に役立たない。この ように鼓脤症はルーメン内容物中に安定な泡泍が発生す ることが原因であるとする研究は多い,19,37-42)，宇睞的 にも卯白を与えて泡沫性状をつくり，発症させた例もあ $3^{43)}$.

ルーメン内容物に発生する泡は, 他の分散系の場合と 同㥞熱力学的に不安定で，特に界面自由工六ルギーが大 きく，正であると不安定となり，消泡して界面積を減少 させ安起する。ところが，ある種の泡の場合には熱力学 的にも安定な場合があり沙，消泡しなくなる。タンパク 質などが起泡丳となっているときには，タンパク質が泡 表面に不可逆的に吸着され，变性し，石けえなぎによる 泡よりはるが定な泡它つくる.また温度変化で自然 に破裂する石け九泡の薄償の厚さは $5 \sim 50 \times 10^{-7} \mathrm{~cm}$ で あるのにタンパク質泡では $2.4 \times 10^{-4} \mathrm{~cm}$ むあり，抬固

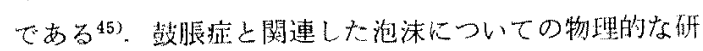
究は多い46-54).

JACOBSON $5^{55)}$ は, ルーメン内容物の発泡力上泡の安 定性を推定するために IVI (Ingesta Volume Increase) と安定 IVI (Stable IVI) を測定した. IVI は採取した ルーメン液 $200 \mathrm{ml}$ を $500 \mathrm{ml}$ の目盛つきのシリンダーに

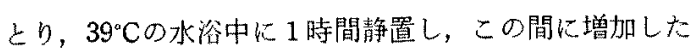
容積の割合をパーセントで表わしたものであり，安定 IVI は IVI を測定後シリンダー中の内容物を容器の底 まで届くようなガラス棒で 12 回憆拌した後容積を測宿 し，加温前の容積のパーセントで表るしたものである. IVI は容積增加能を，安定 IVI はルーメン運動のような 衝整定受けた際の泡涑の安定性の尺应となる。これらの 值はルーメン液の採取時刻や個体の違いに上り変動子る が，鼓脤症状の重さにほほ比例するからルーメンでの安 定な泡沫の形成が発症の一条件となっていることを示睃 している.

発症牛のルーメン内容物のもら一つの特徽は，粘度が 高いことである。ルーメン液の粘度を測定した例は少子 いが, MEYER and BARTLEY ${ }^{56)}$ は鼓脹症の発症頉度や拝状 の軽重度とルーメン液の相対粘度の間には正の相関があ ることを認かている. GUTIERREZ ら ${ }^{57}$ も鼓脹症状の発生 にともなってルーメン液の粘度が高まり，症状が重くな る程高くなるの虎観察している. CHENG and HIRONAKA ${ }^{58)}$ 
は，濃厚飼料でけの飼料堂細かく粉砕して牛に与をると ルーメン内容物は泡洙状军するようになり，ルーメン 液の战度は鞋草の名在給与している場合 7.4 せンチボ イズ（cP）なのが $30.7 \mathrm{cP}$ に上暑することを淮認してい る. 坂内・星野59) もフィードロット敦腿聇牛では, ルー メン液の粘度が $67 \mathrm{cP}$ (正常牛 $16 \mathrm{cP}$ ) にもなること起観 祭している。宇佐川らす牛 ${ }^{60}$ または羊 ${ }^{61}$ で鼓脹症状の発 生にルーメン液の粘度上昇がともなうと趼告している. ルーメン液の発症による粘度增加は，ルーメン内容物牛 の液体部分の割合が減少すること酒関係がある。 た，他の諸要因，特に微生物活動と関連している、ルー メン内容物の粘度増加は泡泍の安定性を䯩好, 発症を助 け，症状の覀化に笴与寸るものと推察される.

発症牛の儿一メン内容物の化学組成にも特徴がある. EMERY Б ${ }^{62)}$ は発症牛では $\mathrm{Na}$, 一キソサミン，嗐素化 合物，脂質などが多いが，その程度恃個体差でも及られ る筙囲のものであるといている. BROWNら ${ }^{63)}$ はルメン内容物のP含量が発症牛で高いことを钼察してい る.ルーメン発酶の通常の最終産物である揮発性脂肪酸 (VFA) やアンモニフ源度は，登症牛で大きな差はないと 颙告されている ${ }^{13,64)}$ 。しかし，これらの報告は対照群も

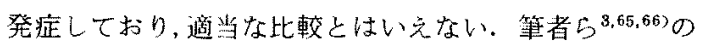
分析で洼，総VFA 溇度には発症牛と正常牛の間に差 はみられないが，発症牛のルーメン内容物は酢酸濃度が 高く，プロビオン酸浱度が低い傾问がみられ, VFA 搆成 割合を計算してみるとこの傾向沬一層明確になり，有意 差がタられる. 㐾って酰酸：プロピオン酸比を算出する と発症牛のそれは症状の軽重に関係なく正常牛の 2 倍以

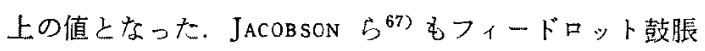
症誘発飼料（大麦 $61 \%$, 大豆粕 $16 \%$, フルフォルファ ミール22\%，食坮 1\%）学給与するとルーメンの VFA は総量が増加し, 酢酸割合が减少し,プロピオン酸割合 が増加するが，給与開始後 6 週間目頃からこの傾向が逆 転し，酢酸割含が增加，プロピオン酸割合が減少しだす ここ落観察している。濃厚飼料と稻わら，バガスなどを 不断給䬣しているフィードロットで操食行動を観察する 之，発症牛は食欲不振となり，特に濃厚鵨料の摄取量が 低下し，粗飼料のそれが多くなる ${ }^{68)}$.この上らな採食行 動の変化が VFA 組成の筡化に閵係あるよらに思われ z.

ルーメン内容物のアンモニア濃度む発症牛で高い傾向 が認められる ${ }^{3,65,66)}$. ルーメンでのアンモ二フの資化 は、いるんな経路で行われるが，適当な炭素源の供給を

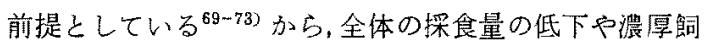
料の掑取䁷の低下がンモニアの利用台㧕制しているの

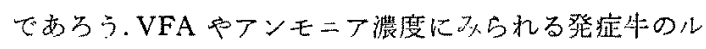
一メン内容物の特徵は，上述のように採食㽢や捸取飼料

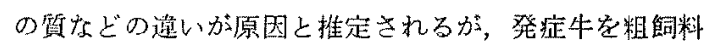
多給の状態にし，発症がみられなくなって正常牛とは

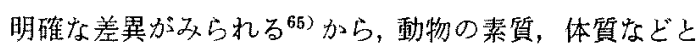
よばれる要因も関与しているのであるう。

ルーメン内容物の $\mathrm{pH}$ は牧草鼓脹の発症によって，あ るいは発症時には低下する74-76) 上久られるが, 必ずしも

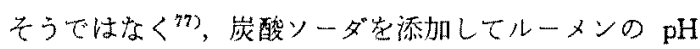
を高くした状況でも発症が認められる ${ }^{78)}$. 鼔脹症誘発能 料を給与したフィードロット鼓脹症でもルーメン $\mathrm{pH}$ 必ずしも低いことはなく，発症との相関は低い18.79)。発 症持に $\mathrm{pH}$ の低下が観察される場合もあるが，同一の飼

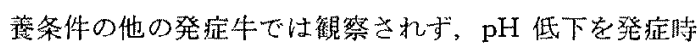
の一般的症状とはみなせない两。一般にルーメンフシド ーシスの場合にはプロトソアが消失するが，鼓脹症牛で はプロトゾフの存在加認められる例が多い3.59,65,66)。この ことは，敁脹症牛のルーメン $\mathrm{pH}$ が極端に低くないこと 范している ${ }^{81)}$. ルーメン内容物の粘度上昇と $\mathrm{pH}$ の関 係を多る上 $\mathrm{pH} 5.5$ ～5.8および 7.5 8.5 の範囲にある 時に粘度上昇の極大值がある ${ }^{58)}$. 従って，粘度上䒜が発 症因上なっているとしても低 $\mathrm{pH}$ 環境加発症の必須条件 ではない。

ルーメンの遊嚄ガス組成は, 発症牛で死亡直後に測定 したもので二酸化岸素 $74.33 \%$ ，メタン $23.46 \%$, 穻葟 $2.21 \%$ で，羊では二酸化崖素が76\%であった $\mathrm{GATE}^{19)}$ もラジノクローバー草地で発症した牛のルーメン ガス組成它分析し，二酸化炭㯏上メタンの構成比染は正 常牛のそれと变りないことを報告している。このように 発症中のルーメンガス組成は正常な範国内にあり，発症 によってルーメン発䣼が著しい变更を受けていないこと が分る.

\section{IV. 泡沫形成に関与する要因}

鼓脹症の発症経緯は，上述の上うに消えにくい泡沫が 形成されるためルーメンで生産されたガスが遊離がスと して放出され，噴門部人移動してあい気反射で排出され る行程が順序上く進まなくなることである，従って安定 な泡沫形成は発症因上して重要な役割を果しているが， 泡沫形成に関与する要因は多く，複雑である。これらの 要因には, 給与-する飼料の質, 量, 形状, ルーメン微生 物，家畜の体質などが揭げられ，研究されている。

1. 飼料とその特定成分

a. タンパク質：牧草鼓脹では牧草の総窒菜含量と発 症染に正の相闒が認められて8-861，特に可溶性の空素区分 


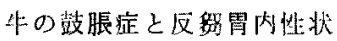

含量との相関が高い ${ }^{86)}$. MILTIMORE $5^{872}$ は葉緑体の分 画 I タメパク質含量上発症率に高い相関 $(\mathrm{r}=0.99)$ が あり，このタンパク筫最が $1.8 \%$ 以上のフルォルファ は危険であると言っている．高等植物の䋖葉部の可溶性 タンパク質は，分画 I とII゙区别され，分画 I は分子量 約 550,000 の醉素タンパク質 (ribulose diphosphate carboxylase $)^{88.89}$ で，葉緑体の主姕タンパク質であ $3^{90)}$. 分画 II は分画 I 以外の可溶性菜タンバタ質で，分 子量 $10,000 \sim 200,000$ のタンパ質を含儿ている ${ }^{01)}$.

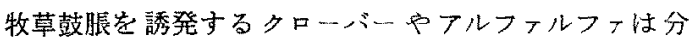
画Iタンパ多質觉乾燥重の 3.9 5.3\% 含えでいるが， 鼓脹をおこさないトレフォィルは約 $0.5 \%$ しか含有しな $\omega^{92)}$.

提食执よび微生物による分解でルーメンに放出された 分画 I タンパク質は,ルーメン液に溶解して表層に移り， そこで変性し，ルーメンの泡沫を安定させる物質とな $ろ^{93)}$. $\mathrm{Ca}$ 户g の結合は分画 I タンパク質の变性を促 進し，症状悪化させる ${ }^{94)}$.これらの分画 I ダンパク質 加発症の引き金になっているという説 ${ }^{85,98,94)}$ に対して タンパク質の分画，分離法に問題があるという批判もあ $b^{49)}$ ，分画 I だけではく分画 I, II こむルーメン液表層 で変性し， pH 5.4〜6.0 の筙国で安定な泡沫形成に颣与. しているとする報告7,49,50,86,95-97) も多い，また，タロー バーの葉部芝取り除き分画 I タンパク質をほさえど含ま

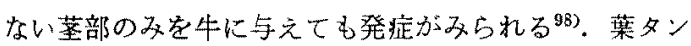
ペク質の 1/3〜2/3 が勗しゃくによってルーメン液に移

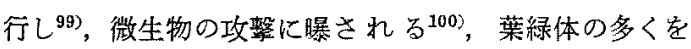
entodinia が採食する ${ }^{101)}$ などを考え合わせると分画 I タ ンパク質が発症時にルーメンに相当量, 常時存在してい るとは考えにくく，分画Iのみを主要な発症因とするこ とは承認しがたい?，促って，牧草中の可溶性タンパク 質含量を指標とする方が合理的で，HowarTH ら ${ }^{86)}$ は三 年間の観察で発症の閧值として牧草乾燥重 I g あたり $1 \sim 6 \mathrm{mg}$ の可溶性タンパタ質の值索揭げており，6 $\mathrm{mg}$ 以 上では発症が直線的に堌加することから現在の発症誘発 フルファルファの可溶性タンパタ質含量を半減する育種 目標を提案している.栽培学的には牧草の可溶性タンパ ク質定減少させるために日照量を制限 ${ }^{102)}$ したり，空素施

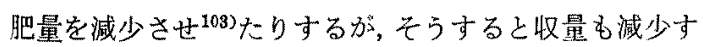
るので問題が残る。

b. 脂 質：ルーメン泡涑の安定性と牧草脂質の関俰 は, 泡沫の安定性を增す, 消泡効果がある, 閣係方ない などの結果に分れており，統一したものはない，牧草の

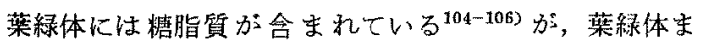
たはその脂質它取り除くとルーメン泡洙の安定性が增 $\dot{9}^{36)}$. STIFEL $5^{94)}$ 極性分子である脂質は，分画 I タ

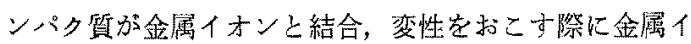
オンを取り合うため泡涑の安定性を減少させる作用肪あ ると主張し，アルファルファの葉緑体脂質と鼓脹症の間 に負の相関方ある年) と言っている. JONE S $^{48)}$ は，赤タ ローバーの極性脂質が分画Iタンパク質泡沫を消泡する 効果定 in vitro で測定し, 消泡勃果は phosphatydyl choline, digalactosyl diglyceride, monogalactosyl dig* lyceride, sulfolipid の順に低下すること示した。

一方, BUCKINGHAM ${ }^{543}$ は脂質はルーメン泡沫中のタン

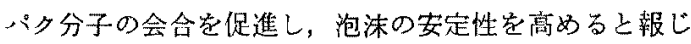
ている. MILTIMORE ら ${ }^{87}$ はアルフォルファ脂質含量と 発症染に正の相関を得ている. BAILEY ら ${ }^{107,108)}$ は赤ク口 一ハーーの糖脂貿などについて研究し，鼓脹症と関連が低 いこと老䘽察している. FRASER ${ }^{109)}$ もクロードー給与の 発症牛と非発症牛でルーメンの脂質分画に差がみられな いと言っている.

アルファルファのリポタンパ質量と in vitroでの

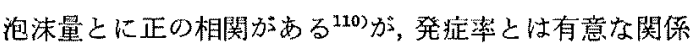
はみられない ${ }^{86)}$.

c. 糖 質：易利用性の糖質を多く含む飼料は，ルー メンでのガス生産苍促進し，鼓脹症の誘因となる可能性 がある111.ペタチン,グルコース,ガラクトースなどを了 ルファルファ瀻維に添加給与するとガス生産が高まり， 泡沫の安定性が增对 ${ }^{112,113}$ 。フィードロット鼓脹症でる ルーメン液の糖質量とルーメン液の粘度上昇は比例す $3^{114,115)}$ ，マメ科牧草に多く含まれるへタチンはぺク夕 一ゼによってメチルエステル結合が加水分解されるが， その際 $\mathrm{Ca}^{+}$イオンが存在するとゲル化しやすい。このた めルーメン液の粘度を上昇させ，ルーメンガス它闑じ込 め，ガスの放仕过困難にすることが考党られる ルファルファのペタチン含量 ${ }^{119}$ または家蓄のペクター ゼ掑取量120,121 乙発症慗には正の相関が名られ，ペクタ 一ゼ阻害郕 alkyl aryl sulfonate の給与.で牧草鼓脹の発 生が防止できた ${ }^{222}$.これらの結果はペクチンがルーメン の泡沫の安定性堂高め，発症の誘因となる可能性を示す が，一般にペクチンはルーメンで消化されやすく，ルー メンに蓄積することはない年3-126). またぺタチンは in vitroでは, フルファルファ抽出物の泡の安定性定増

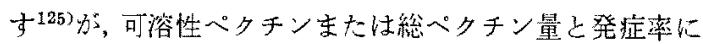
䦭連は多られないという報告 ${ }^{127)}$ もるからら、へタチンだ けが原因物質と恃空い難い，往って垷在のとこる，パ チンは主要な泡沫形成物質ではなく，ルーメン液の阽度 を高めることによって葉タンハタ質の泡沫を安定化し， 発症に符与していると考元られている 


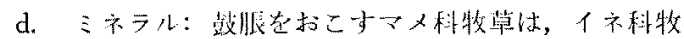
草より $\mathrm{Ca}, \mathrm{Mg}$ 含量肪高く，羊に $\mathrm{Ca}$ または $\mathrm{Mg}$ 塩や尿

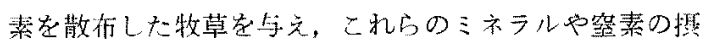
取量点增加させると発症頻度が高まり ${ }^{130)}$, 症状が重くな

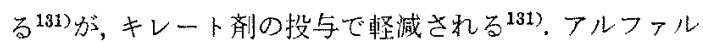
ファ葉の $\mathrm{Mg}^{84,94)}, \mathrm{Ca}, \mathrm{Ni} ， \mathrm{Zn}^{877}$ 含量と発症率に正の 相関吕みられ， $\mathrm{Ca} / \mathrm{P}$ 比の高い飼料は発症を起しやす い132)，これらのミネラルは，上述のタンパク質やぺクチ ンまたはサポニンと反応して泡涞を安定化することによ って発症誘因となると考元られている し, フルファルファ菜の $\mathrm{Ca}^{85,947}, \mathrm{Mg}^{87)}$ 合量と発症率に 負の相関があるという逆の関係も得られており，またミ ネシル含量との相関はない上いう結果 ${ }^{83,134-137)}$ も多く, 明確ではない。

e. サポニン：サポニンは植物界に分布する配煻体 で，マメ科牧草のそれはトリテルペノイドをアダルコン 上する.サポニンは界面活性物質で泡犬゙つ水溶腹をつく るが，溶血作用や他の楽理作用も認められている。家童 に掑取されると消化管内微生物によってサポニダンと烠 に分解され，サポニダンはさらに分解定受ける ${ }^{138,1399}$. 鼓 脹誘発牧草は乾燥重の $0.2 \sim 1.8 \%$ のサポニン老含有し, 安公な牧草の 2 18 倍も高い: ${ }^{1403}$. LINDAHL ら ${ }^{141)}$ は了ル ファルファのサポニンを経口的または静注して羊に与 え, 鼓脤症状を発生させた。 GUUTERreZ ら ${ }^{142)}$ はフルフ フルファ生草を与えている牛からサポニン分解菌を分激 し，乙れらの分解菌のサポニン発酵にともなって大量の 粘筫物 (slime) が生産されることを示しだ．これらの研 究からサポニンがルーメンの泡沫形成赫よでその安定化 に役立り，発症に寄与していると推察されているが，上

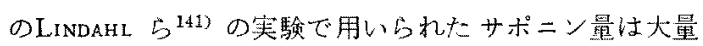
すぎることら), サポニンによる泡は $\mathrm{pH} 5.0$ で最む安定 で，牧草鼓脹の際のルーメン内容物の $\mathrm{pH} 6.0$ 上りかな り低いとと脑などからサポニンが泡涑形成に主要な役割 を果しているとはみられていない、143.144).

サポニンの筋肉の呼吸抑制など薬理作用上発症との関 連む疑問視されている年年,145-147)，

f. タンニン：タンニンは水溶性の植物成分であるが 化学的には分子量 $500 \sim 3,000$ の多価フェノールで, タン パク質と絬合し，沈でんする.しかし，タンニンの種類は 多く，赫口ーバーのタンニンの上うにタンパ質龙沈 でんさせないものもある。鼓脹で問題になる可溶性葉夕 ンパク質，哽液タンパク質などを効果的に沈でんさせる タンニンは縮合タンニン（flavolans）で 科牧草に多く含まれている ${ }^{48}$. KENDALL ${ }^{149)}$ は鼓脹誘発 牧草の菜抽出物での泡涞形成は，タンニンの添加で抑制

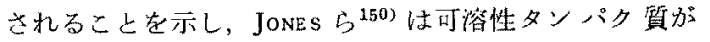
誘発牧幕加ら多く抽出で当が, 安全牧草からは除夕 ンニン剂を添加した時のみ抽出可能であることを確め た。またタンパク質沈でえをおこすタンニン浱度と発症 率には負の相関がみられる84,151-153)，これらの結果は， タンニン含量の高い牧草では勗しゃくまたはルーメンで の分解過程でタンニンが放出され，可溶性タンパク質と 結合沈でんする，またはタンニン一サポニン結合定生し る ${ }^{154)}$ ため起泡が咸少し，発症が㧕制される可能性を示し ている. 従って,タンニン含量に着目した牧草の育種は 発症予防の見地汃ら意義がある ${ }^{48,148,150)}$.

g. 飼料の物理性：鼓脹症は粗飼料の不足した状態で おきやすく,フィードロットでは涱厚飼料が攝取量の半 分以上之なった时155)，特に肥育仕上げ期に発症頻度が高 い. 牧草鼓腿も多汁で粗せ九い含量の少ない牧草が誘発 する. 発症牛に粗飼料を飽食させて飼い直しをすると治 痹する.乙の粗飼料効果の本体は必ずしも明確ではない が, 粗飼料の不足がルーメン運動, あい気反射, 唾液分 泌などの失调を来たすことと関倸がある 草も唾液分泌の刺激が十分でなく、ルーメン内容物の粘 度を高め, 発症党誘発しやすい, 161,163)。

同一の飼料で毛粉碷の粒度に上って影響を受け，粒度 が細かい程発症頻度は高く, 症状も重くなる58.59,158.164${ }^{166)}$. この粉所奶果は上記のルーメン運動 ${ }^{165.167)}$, 恓液分 泌 ${ }^{168)}$ 人の影響に加えてルーメンでの飼料の分解速度が 高まり,ガス生産加加速される ${ }^{59)}$ ともに泡沫安定物質 が多く放出されるためと考兑られる。

2. ルーメン微生物

a. 細菌：牧草豉髟の場合，ルーメン細菌の数㧍よび種 類に大きな変化は生じないと郝告されている159,167-1699. このことはルーメン発酵の最終産物であるガス ${ }^{19,1703}$, $\mathrm{VFA}^{19,159)}$ ，溁素化合物 ${ }^{32,159)}$ などに大差なく、ルーメン $\mathrm{pH}^{322}$ にも差異がみられないことと符号する゙．しかし発 症しない牛ではムチン分解菌数が多い171,172)，発症牛の ルーメン液の方が in vitro での発酵速度は速い ${ }^{19)}$ とか 差異がない訳ではない，鼓脹誘発牧草は細菌による分解 が急速 ${ }^{173)} ゙$ でがスが生産される速度も速い, ${ }^{174)}$.

HUnGATE ら ${ }^{19}$ 注，発症因として微生物による slime 形成を示唆し, GUTIERRE $25^{142.175)}$ はサポニン分解菌 (Butyrivibrio fibrisolvens, Bacteroides ruminicola など) が時に大量の slimeをつくること,この slime は核酸成 分上して RNAのみ含み含，サポニンの分解で生じる サポニゲン由来のものであり ${ }^{35,1699}$, フィードロット鼓脹 症の slime 方微生物起源のむのである ${ }^{57}$ のと対照的であ ること觉竍告している. slime の形成は，ルーメン液の 
粘度を增し泡洙を安定化するので登症の原因となるが， 発症牛で Butyrivibrios 数が特に增加することもなく ${ }^{167)}$, 培養菌でタられる現象が艺のまま発症時に㧍きていると 悑らない，同様なことが Streptococcus bovis による デキストラン slime $\mathrm{s}^{176,178\rangle}$ についても言える.

フィードロット瑴脹の場合も細菌の翌動は複雑で, 同 一飼料で発生した 2 頭についてみると細菌相の一致がみ られす ${ }^{80)}$, 細囷の数や種類が著しく異っている固体です

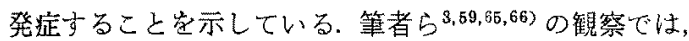
発症によって小型のグラム(一)球菌，グラム $(+)$ 球菌, グラム(一)桿菌，グラム $(+)$ 桿囷に有意な変化が少られ た。登症にともなら細囷相の変化は slime 非成との関俰 で研究され，多くの報告9,65,56,59,81,114,176-180) 少好り，特 に S.bovis, Megasphaera elsdenii の変化が注目されて いるが，それらの詳細については総説 ${ }^{9,10}$ を参照された W.

b. プロトゾア：登症にともなうプロトゾアの変化も 興味あるむので，発症因として多くの仮説が立てられて いる. CLARKE ${ }^{181,182)}$ は発症にともなって holotrich プロ トゾフの堿少肪おきることに注目し，誘発飼料の椇取を ともにこのブロトソブの崩溒がおこり，放出された細胞 内容物，多糖や恔酸がルーメン内谷物の粘度老高め，泡 洙の安定化老促進し，発症因となるとした。こらのプ ロトゾアに特異的な抗プロトゾア剂 (1，2-dimethyl-5-

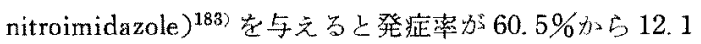
\%に低下する ${ }^{184}$ こと,プロトゾア細胞内物質が $\mathrm{pH}$. 5 6.5 の範囲で強鞋な泡沫索形成することなどから, holotrich プロトゾア説には根抛があるしかし，これらの プロトゾアが完全にルーメンから除かれても発症がみら れ，上記の抗プロトソフ剂はルーメン細菌にも作用があ る ${ }^{184)}$, CLARKE の钼察した holotricha の発聇による急激 な减少を他の例では再確認できない, $3,66,81,88$ など弱点が

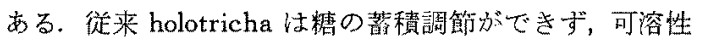
の糖質が十分与えられると蓄積過萪となって崩壊すると 言われていた肪，最近 PRINS ら ${ }^{185,186)}$ の研究によれば そのようなことはなく，ルーメン環境の㯖化，とりわけ $\mathrm{pH}$ の低下（pH 5.0以下）によるものである。鼓脤症の 埸合ルーメン $\mathrm{pH}$ が 5.0 以下になることは希れであるか 5, holotricha 説にはこの点も具合少声い。

Epidinium 属のプロトソアが消泡作用のある葉緑体脂 質安摄取するため発症するという説 ${ }^{101)}$, Ophryoscolex 属 のガス生産に原因艺求める説 ${ }^{187)}$ などもあるが，発症洔 のプロトソア組成調べた結果3,59,66,81,883 からは支持さ 虬ていな。

プロトゾフを発症因をたは誘発補助生物とみる説とは
逝にプロトゾアの存在が発症を抑制し，元の桠端な減少

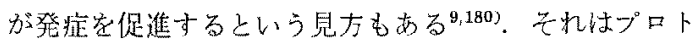
ソ゚アが糖質などを摄取し188 1903，ルーメンでの発醳が急 激に進完のを抑えるとともに鼓腿誘発に関係のるる絹菌

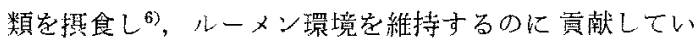
るからである。

c. ルーメン発酵産物: ルーメンで微生物活動の結果 産出される発酵最終産物であるVFA，アンモニフ,ガス などの組成，浱度については川章で述べた。VFAは高

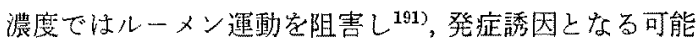
性があるが，通常観察される発症牛のVFA 浱度，組成

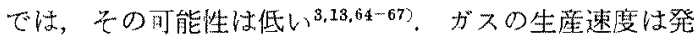

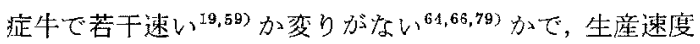
より排出速度に開題のあることが分る、ルーメンでヒス チジンの脱炭酸によって生じるヒスタミンおよび類似物

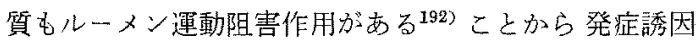
物質の一つと考光られるが，発症牛で特以高浱度である こともなく，経口的に投与してもルーメン機能障害が灭 られず193)，発症もしない"9からとスタミンが発症因であ

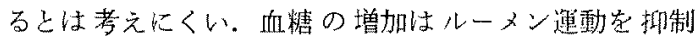
し，インスリンによる低血精は逆に促進する194ことが

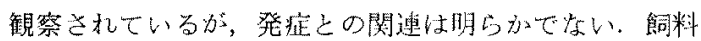
のルーメンから下部消化管への移行速度なに゙もルーメン 発醭比影響を与えるので発症と関係がある. 食塩添加量

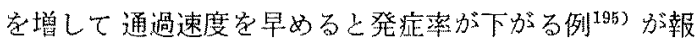
告されている。

\section{3. 家音の体質に由来する発症因}

鼓脹症柱同一の飼皦条件である個体は発症し，他の個 体は発症しないというような家音の体質また愫質に

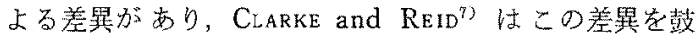
脤症に対する感受性の薏いとし，感受性の高い(High Susceptibility: HS) 個体, 低い (Low Susceptibility: LS）個体と区別し，㙋伝的差異であるとしている，杂机

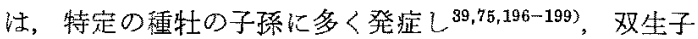

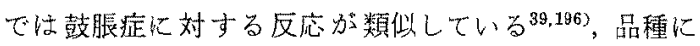
よって感受性が異なる199,200)などの観察に基づいてい 市.

感受性要因の本態佉塆液分泌の速度や量，唾液組成， あい気及射就よびルーメン運動，食物の下部消化管への 流動，ルーメン微生物相とその代謝速度等々の差異とし て把えられている。これらの研究の詳細については，紙 数の制約上触孔られないので総詯 $2,7,8,10,32,75)$ 范参照され t心.

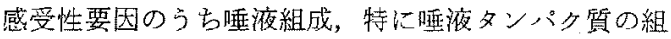

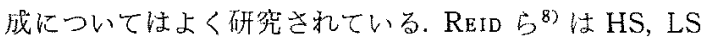


動物の睡液タンパク質をポリアクリルアミドダルの㻨気 泳動で分画し，10個の主要なタンパ質定確認し，この うち第 4 ，第 6 ，第 10 のバンドに分画されたタンパク質 量がHS とLSで明確に買なり、第 4, 第 6 タンパク質 はHSで多く、第10 タンパ質は少ないこと定示した。 JONES ら ${ }^{2011}$ は最近これらの棰液タンパク質をさらに

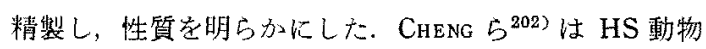
の睡液は粘度が低く、乾物量が少なく、タンパク質量が 多いが，糖タンパク質バンドが少なく，糖タンパク質で LS 動物と区別が可能であると言っている.

唾液のタンパク質については，従来泡沫形成促進また は安定作用7,48,52,2037 と逆の消泡作用 ${ }^{204,205)}$ の相反する性 質が報告されているが，上記の電気泳動で分画された夕 ンパク質が泡沫形成，または消泡にどのように関的って いるかは不明である.しかし，唾液タンパク質の差異で HS，LS 動物を区别できるとすれば産業上も極めて有益 ですり, 発症機作の研究にる大いに役立つ.

牛の晴液または血清にS. bovis 乙特異的に凝集反応を おこす免疫ダロプリンが含まれているという報告8, 2061も 発症と唾液の関係を研究するのに與味深い。

$$
\text { むすび }
$$

牛の呚脹症は牧草鼓脹, フィードロット鼓脹々も畜牛 の1\%程度に発症がタられ，音産経営上軽視できない病 父である。泡沫性鼓脤はルーメン液の粘度が高变り，儿 ーメンガスが遊離ガスとして放出されず，無数の泡沫と なって液中に閉じこめられ，西い気反射での排出が困難 となり、ルーメンに蓄積する。この消えにくい泡沫の形 成には飼料成分の多くが関連定持ち，ルーメン微生物 や家畜の体筫も梁く関加ており，複数の要因が関与. していると思われる。発症因については多くの提案があ り，相応する根拠方示されている。 しかし，現在でも HUNGATE ${ }^{6}$ ) が言うように“特定の仮説 (発症因) 䘮世界 の各地で多くの研究室が実証するまでは，不確実性が残 る”段階にあり，今後の研究が期待される.

本稿では述べなかったが，予防・治療研究も多くあり， この面からの発症因の解明る期待できる. 最近イオノフ オフ抗生物質，モネンシン，サリノマイシンに治療効果

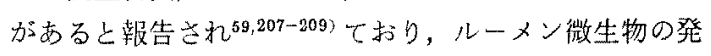
症への関与方注目される。

\section{文献}

1) 小林一雄・山本道生, 音廒技術研修会会報（爱知 県畜産課) 91-94. 1980.

2) Clarke, R. T. J. and C. S. W. Reid, J. Dairy Sci., 57: 753-785. 1974.
3）坂内良二・星野貞夫，日畜会報，52：118-124. 1981.

4) 篠崎謙一, 乳牛の科学 (梅津元昌編), 357-374. 農文協，東京. 1966 .

5) COLE, H. H. and J. M. BOdA, J. Dairy Sci, 43: 1585-1614. 1960.

6) Hungate, R. E., The Rumen and Its Microbes. 442-454. Academic Press. New York and London. 1966.

7) Clarke, R. T. J. and C. S. W. Reid, in Physiology of Digestion and Metabolism in the Rumen. (Phillipson, A. T., ed.) 599-606. Oriel Press. Newcastle upon Tyne. 1970.

8) Reid, C.S. W., R. T. J. Clarke, F.R. M. Cockrem, W. T. Jones, J. T. McIntosh and D. E. Wright, in Digestion and Metabolism in the Ruminant. (McDonald, I. W. and A. C. I. Warner eds.) 524-536. Univ. New England, Armidale. 1975.

9) Bartley, E. E., R. M. Meyer and L. R. FinA, in Digestion and Metabolism in the Ruminant. (McDonald, I. W. and A.C. I. Warner eds.) 551-562. Univ. New England, Armidale. 1975.

10）星野貞夫，畜産の研究，36：19-21．263-268. 379383. 1982.

11) Cole, H. H., R. W. Dougherty, C. F. Huffman, R. E. Hungate, M. Kletber and W. D. McClay, Natl. Res. Council, Publ. 388. 1956.

12）原茂，牛病学，(大森常良䄸）721-728. 近代出 版, 東京. 1980 .

13) Elam, C. J., J. Gutierre $Z$ and R. E. Davis, J. Anim. Sci., 19: 1089-1097. 1960.

14) McArthur, J. M. and J. E. Miltimore, Can. J. Anim. Sci., 41: 187-196. 1961.

15) Cresswell, E., Nature, 186:560-561. 1960.

16) Hoernicke, H. W. F. Williams, D. R. Waldo and W. P. Flatt, Proc. 3 rd Symp. Energy Metabolism, 165. 1964.

17) Washburn, L. E. and S. Brody, Miss. Agr. Exp. Sta. Res. Bull., 263: 1-40. 1937.

18) Colvin, H. W., J. D. Wheat, E. A. Rhode and J. M. Boda, J. Dairy Sci., 40: 492-502. 1957.

19) Hungate, R. E., D.W. Fletcher, R. W. Dougherty and B. E. Barrentine, Appl. Microbiol., 3: 161173. 1955.

20) Kleiber, M., Natl. Res. Council Publ., 388. 1956.

21) Dougherty, R. W. and H. M. Cook, Am. J. Vet. Res., 23: 997-1000. 1962.

22) Barnett, A. J. G. and R. L. Reid, Reactions in the Rumen. 161-169. Edward Arnold. London. 1961.

23) Dougherty, R. W., in Digestive Physiology and Nutrition of the Ruminant. (LEwIs, D. ed.) 7987. Butterworths. London. 1961.

24) Dougherty, R. W., C. H. Mullenax and M. J. Allison, in Physiology of Digestion in the 
Ruminant. (Dougherty, R. W. ed.) 159-170. Butterworths. London. 1965.

25) Cole, H. H., C. F. Huffman, M. Kleiber, T. M. Olson and A. F. Schalk, J. Anim. Sci., 4: 183236. 1945 ,

26) Dougherty, R. W., J. Am. Vet. Med. Ass., 96: 43-46. 1940.

27) Dzuik, H. E. and A. F. Sellers. Am. J. Vet. Res., 16: 499-504. 1955.

28) Stevens, C. E. and A. F. Sellers, Am. J. Vet. Res., 20: 461-482. 1959.

29) Dougherty, R. W. and C. D. Meredith, Am. J. Vet. Res., 16: 96-100. 1955.

30) Dougherty, R. W., R. E. Habel and H. E. Bond, Am. J. Vet. Res., 19: 115-128. 1958.

31) Andersson, B., Kitchell and N. Persson, J. Physiol., 147: 11. 1959.

32) Mendel, V.E. and J. M. Boda, J. Dairy Sci., 44: 1881-1897. 1961.

33) Bartley, E. E., Feedstuffs, 30: 70. 1958.

34) Bartley, E. E. and R. Bassette, J. Dairy Sci., 44: $1365-1366.1961$.

35) Gutierrez, J., H. W. Essig, P. P. Williams and R. E. Davis, J. Anim. Sci., 22: 506-509. 1963.

36) Mangan, J. L., N. Z. J. Agr. Res., 2: 47-61. 1959.

37) Boda, J. M., P. T. Cupps, H. Colvin and H. H. Cole, J. Am. Vet. Med. Ass. 128: 532-535. 1956.

38) Clark, R., Onderstepoort J. Vet. Sci., 23: 389393. 1948.

39) Johns, A. T., N. Z. J. Sci. Tech., 36A: 289-320. 1954.

40) Quin, J. I., Onderstepoort J. Vet. Sci. Anim. Ind., 18: 113-117. 1943.

41) Reid, C. S. W., Proc. 8 th Int. Grassl. Congr., 668-671. 1960.

42) Walker, D. M., Aust. Vet. J., 36: 17-20. 1960.

43) Boda, J. M., B. S. Silver, H. W. Colvin and H. H. Cole, J. Dairy Sci., 40: 759-767. 1957.

44) Ross, S., Chem. Engineering Progress, 63: 4147. 1967.

45) LABY, R. H., in Digestion and Metabolism in the Ruminant. (McDonald, I. W. and A. C.I. WARnER eds.) 537-550. Univ. New England, Armidale. 1975.

46) Laby, R. H., N. Z. J. Agr. Res., 12： 427-436. 1969.

47) Laby, R. H. and R. O. WeEnink, N. Z. J. Agr. Res., 9: 839-850. 1966.

48) Jones, W. T., Ph. D. Thesis. Massey Univ. N. Z. 1971.

49) Jones, W. T. and J. W. Lyttleton, N. Z. J. Agr. Res., 12: 31-46. 1969.

50) Jones, W. T. and J. W. Lyttleton, N. Z. J. Agr. Res., 15: 267-278. 1972.

51) Jones, W. T. and J. W. Lyttleton, N. Z. J. Agr. Res., 15: 506-511. 1972.
52) Jones, W.T. and J. W. Lytrleton, N. Z. J. Agr. Res., 16: 161-168. 1973.

53) Buckingham, J.H., J. Sci. Food Agr., 21: 441445. 1970.

54) Buckingham, J. H., Ph. D. Thesis. Victoria Univ. N. Z, 1971.

55) JaCobson, D. R., I. L. Lindahl, J. J. McNellL, J. C. Shaw, R. N. Doetsch and R. E. Davis, J. Anim. Sci., 16: 515-524. 1957.

56) Meyer, R. M. and E. E. Bartley, J. Anim. Sci., 34: 234-240. 1972.

57) Gutierrez, J., R. E. Davis and I. L. Lindahl, Appl. Microbiol., 9: 209-212, 1961.

58) Cheng, K. -J. and R. Hironaka, Can. J. Anim. Sci., 53: 417-422. 1973.

59) Sakauchi, R. and S. Hoshino, Z. Tierphysiol Tierernähr. Futtermittelkd., 46: 21-33. 1981.

60）宇佐川智出，石川農短大啹，4：30-35，1975.

61）宇佐川智也・津由策三，石川農短大報，7：37-41。 1977.

62) Emery, R. S., C. K. Smith, R. M. Grimes, C. F. Huffman and C. W. Duncan, J. Dairy Sci,, 43: 76-80. 1960.

63) Brown, L. R., R. S. Allen, R. H. Johnson and N. L. JACOBson, Proc. 5 th Conf. Rumen Function, Chicago. 9. 1960.

64) Elam, C. J. and R. E. Davis, J. Anim. Sci., 21: 568-574. 1962

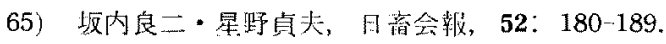
1981.

66) Sakauchi, R. and S. Hoshino, J.Gen. Appl. Microbiol., 27: 145-155. 1981.

67) Jacoeson, D. R., I. L. Lindahl J.J. McNeill, J. C. Shaw, R. N. Doetsch and R. E. Davis, J. Anim. Sci., 17: 304-312. 1958.

68）圾内良二・星野南夫，日䀂会笮， 52：236-238. 1981.

69) Hoshino, S., Jpn. J. Zootech. Sci., 36: 266-273. 1965.

70) Hoshino, S., K. Sarumaru and K. Morimoto, J. Dairy Sci., 49: 1523-1528. 1966.

71) Hoshino, S., H. Tsubota and K. Morimoto, Jpn. J. Zootech. Sci., 42: 103-110. 1971.

72）星野真夫，第 10 回ルミノロジー研究者のつどい, 江別市, 21-37. 1981.

73) Tsubota, H. and S. Hoshino, J. Dairy Sci., 52: 2024-2028. 1969.

74) Johns, A. T., J. L. Mangan and C. S. W. Reid, N. Z. Vet. J., 5: 115-124. 1957.

75) Johns, A. T., J. L. MAngan and C.S. W. Reid, Proc. N. Z. Soc. Anim. Prod., 18: 21-30. 1958.

76) Blake, J.T., N. L. Jacobson and R. S. Allen, Am. J. Vet. Res., 18: 756-760, 1957.

77) Mendel, V. E*, Ph. D. Thesis. Univ. California. 1960.

78) Hartman, P. A., R. H. Johnson, L. R. Brown, N. 
L. Jacobson and R. S. Allen, Proc. 5 th Conf. Rumen Function, Chicago. 20-21. 1960.

79) Elam, C. J. and R. E. Davis, J. Anim. Sci., 21: 327-330, 1962.

80) Bryant, M. P., I. M. Robinson and I. L. Lindahl, Appl. Microbiol., 9: 511-515. 1961.

81) Gutierrez, J., R. E. Davis, I. L. Lindahl and E. J. Warwick, Appl. Microbiol., 7: 16-22. 1959.

82) Reiset, J., Compt. Rend., 66: 176-177. 1868.

83) Miltimore, J. E., J. L. Mason and J. M. McArThur, Can. J. Anim. Sci., 44: 309-314. 1964.

84) JefFers, B. R., S. H. Synhorst, N. L. Jacobson, D. K. Hotchkiss and R. L. Vetter, Proc. 8 th Conf. Rumen Function, Chicago. 2, 1965.

85) Stifel, F. B., R. L. Vetter, R. S. Allen and H. T. Horner, Phytochem., 7: 355-364. 1968.

86) Howarth, R. E., W. Majak, D. E. Waldern, S. A. Brandt, A. C. Fesser, B. P. Goplen and D. T. Srurr, Can. J. Anim. Sci., 57: 347-357. 1977.

87) Miltimore, J. E., J. M. McArthur, J. L. Mason and D. L. Ashisy, Can. J. Anim. Sci, 50:61-68. 1970.

88) Mayaudon, J., Enzymologia, 18: 343-354. 1957.

89) Trown, P. W., Biochem., 4: 908-918, 1965.

90) Lytrleton, J. W. and P.O. P. Tsó, Arch. Biochem. Biophys., 73: 120-126. 1958.

91) Singer, S. L., L. Eggman, J. M. Campbell and S. G. Wildman, J. Biol. Chem., 197: 233-239. 1952.

92) McArthur, J. M. and J. E. Miltimore., Proc. 10 th Int. Grassl. Congr., 518-521. 1966.

93) McArthur, J. M., J. E. Miltimore and M. J. Pratt, Can. J. Anim. Sci., 44: 200-206. 1964.

94) Stifel, F. B., R. L. Vetter and R. S. Allen, Agr. Food Chem., 16: 500-504. 1968.

95) McArthur, J. M. and J. E. Miltimore, Can. J. Anim. Sci., 49: 59-67. 1969.

96) Howarth, R. E., J. M. McArthur, M. Hikichi and S. K. SARKar, Can. J. Anim. Sci., 53: 439 443. 1973.

97) Howarth, R. E., S. K. Sarkar, A. C. Fesser and G. W. Schnarr, J. Food Agr. Chem., 25: 175179. 1977.

98) Newbold, R. P., Massey Dairy Farming Ann., 105. 1953.

99) Reid, C.S. W., J. W. Lytteeton and J. L. ManGAN, N. Z. J. Agr. Res., 5: 237-248. 1962.

100) Hazel wood, G. P., G. A. Jones and J. L. Mangan, J. Gen. Microbiol., 123: 223-232. 1980.

101) Oxford, A. E., N. Z. J. Agr. Res., 1: 809-824. 1958.

102) Walgenbach, R.P. and G. C. Marten, Crop Sci., 21: 859-862. 1981.

103) Walgenzach, R. P. and G. C. Marten, Crop Sci., 21: 852-855. 1981

104) Benson, A. A., J. F. Wintermans and R. Wiser, Plant Physiol., 34: 315-317. 1959.
105) WeEnink, R. O., N. Z. J. Sci., 2: 273. 1959.

106) Weenink, R. O., Biochem. J., 82: 523-527. 1962.

107) Bailey, R. W., N.Z. J. Agr. Res., 7: 417-426. 1964.

108) Russell, G. B. and R. W. Bailey, N. Z. J. Agr. Res., 9: 22-31. 1966.

109) Fraser, J. G., N. Z. J. Agr. Res., 4: 224-231. 1961.

110) Rommann, L. M., E. D. Gerloff and R. A. Moore, Crop Sci., 11: 792-795. 1971.

111) Quin, J. I., Onderstepoort J. Vet. Sci., 18: 91112. 1943.

112) Conrad, H. R., W. D. Pounden, O. G. Bentley and A. W. Fetter, J. Dairy Sci., 41: 1586-1592, 1958.

113) Head, M. J., Nature, 183: 757. 1959.

114）宇佐川筸过・津田栄三，石川農短大報，8：39-44. 1978.

115) Meyer, R. M. and E. E. Bartley, J. Anim. Sci., 33: 1018-1021. 1971.

116) Gupta, J. and R. E. Nichols, Am. J. Vet. Res., 23: 128-133. 1962.

117) Nichols, R. E., Can. Vet. J., 3: 84-89. 1962.

118) Nichols, R. E., Nord. Veterinaermed., 16: 355360. 1964.

119) Pounden, W. D. and H. R. Conrad, Ann. Rep. Ohio Agr. Exp. Sta. 1959.

120) Nichols, R. E. and D. C. Deese, Am. J. Vet. Res., 27: 623-627. 1966.

121) Nichols, R. E., D. C. Deese and J. LANG, Am. J. Vet. Res., 29: 2005-2008. 1968.

122) Nichols, R. E., Am. Vet. Med. Ass. J., 143: 998 999. 1963.

123) Dekker, R. F.H., G. N. Richards and M. J. Playne, Carbohyd. Res., 22: 173-185. 1972.

124) Dehority,B. A., R. R. Johnson and H. R. Conrad, J. Dairy Sci., 45: 508-512. 1962.

125) Pressey, R., S. H. Synhorst, J. Bertram, R. S. Allen and N. L. Jaconson, J. Anim. Sci., 22: 970-978. 1963.

126) Wright, D. E., Arch. Biochem. Biophys., 86: 251-254. 1960.

127) Pressey, R., S. H. Synborst, R. S. Allen, N. L. Jacobson and C. P. Wilsie Agr. Food Chem., 11: 396-399. 1963.

128) Wright, D. E., N. Z. J. Agr. Res., 4: 203-215. 1961.

129) Jones, W. T., J. W. Lyttleton and J. L. Mangan, N. Z. J. Agr. Res. 21: 401-407. 1978.

130) Warner, D., K. J. Smith and W. Woods, J. Anim. Sci, 21: 757-761. 1962.

131) Smith, K. J. and W. Woods, J. Anim. Sci., 21: 798-803. 1962.

132) Cooper, H. P., S. C. Agr. Exp. Sta. Agron, Soils Res. Bull., 22. 1960.

133) Harris, P. J. and F. Sebba, Nature, 208: 869 


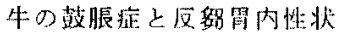

871. 1965.

134) Miltimore, J. E., J. M. McArthur, J. L. Mason and R. B. Carson, Can. J. Plant Sci., 44: 175181. 1964.

135) Conrad, H. R., W. D. Pounden and B. A. DehoRITY, J. Dairy Sci, 44: 2015-2026. 1961.

136) Jackson, H. D., R. L. DeVhult, S. A. McNarry, B. W. Hatcher and G. D. Goetsch, J.Anim. Sci., 21: 235-240, 1962.

137) McNairy, S. A., Diss. Abstr. Sect. B, 27: 388389. 1966.

138）落荷 登・柴田章夫, 日草誌，24：71-73. 1978.

139) Mroga, K, and F. Shibata, J. Japan Grassl. Sci., 24: 17-26. 1978.

140) Maclay, W. D. and C. R. Thompson, Natl. Res. Council, Publ., 388. 1956.

141) Lindahl, I. L., A. C. CoOK, R. E. Davis and W. D. Maclay, Science, 119: 157. 1954.

142) Gutierre Z, J., R. E. Davis and I. L. Lindahl, Science, 127: 335. 1958.

143) Maymone, B., Ann. del. Speriment. Agr., 17: 131. 1963.

144) Majak, W., R. E. Howarth, A. C. Fesser, B. P. Goplen and M. W. Pedersen, Can. J. Anim. Sci., 60: 699-708. 1980.

145) Dzuik, H. E., A. F. Seleers and C. E. Stevens, Am. J. Vet. Res., 22: 287-297. 1961.

146) Jackson, H. D., R. A. Shaw, W. R. Pritchard and B. W. Hatcher, J. Anim. Sci., 18: 158-162. 1959.

147) McNairy, S. A., G. D. Goetsch, B. W. Hatcher and H. D. JaCkson, J. Anim. Sci., 22: 61-65. 1963.

148) Jones, W. T., L. B. Anderson and M. D. Ross, N. Z. J. Agr. Res., 16: 441-446. 1973.

149) Kendall, W. A. Crop Sci,, 6: 487-489. 1966

150) Jones, W. T., J.W. Lyrtleton and R. T.J. Clarke, N. Z. J. Agr. Res., 13： 149-156. 1970.

151) Jones, W. T. and J. W. Lyttheton, N. Z. J. Agr. Res., 14: 101-107. 1971.

152) Reid, C.S. W., M. J. Ulyatt and J.M. Wilson, Proc. N. Z. Soc. Anim. Prod., 34：82 93. 1974.

153) Goplen, B. P., R. E. Howarth, S. K. Sarkar and K. Lesins, Crop Sci., 20: 801-804. 1980.

154) Cheeke, P. R., Can. J. Anim. Sci., 51: 621-632. 1971.

155) Jacobson, D. R., Ph. D. Thesis. Univ. Maryland. 1956.

156) Cole, H. H., S. W. Mead and M. Kletber, Calif. Agr. Exp. Sta. Bull., 662. 1942.

157) Cole, H. H., S. W. Mead and W. M. Regan, J. Anim. Sci., 2: 285-294. 1943.

158) Mead, S. W., H. H. Cole and W. M. Regan, J. Dairy Sci., 27: 779-791. 1944.

159) Clarke, R. T. J. and R. E. Hungate, N. Z. J. Agr. Res., 14: 108-121. 1971.
160) Clark, R. and K.E. Werss, J.S. Afr. Vet. Med. Ass., 23: 163-165. 1952.

161) Werss, K. E., Onderstepoort J. Vet. Res,, 26: 241-250. 1953.

162) Werss, K. E., Onderstepoort J. Vet. Res., 26: 251-283. 1953.

163) Meyer, R. M., E. E. Bartley, J. L, Morrill and W. E. Stewart, J. Dairy Sci., 47: 1339-1345. 1964.

164) Cole, H. H. and S. W. Mead, Science, 98: 543544. 1943.

165) Colvin, H. W. and L. B. Daniels, J. Dairy Sci., 48: 935-941. 1965.

166) Preston, T. R., J. N. Aitken, F. G. Whitelaw, A. Macdearmid, E. B. Philip and N. A. Macleod, Anim. Prod., 5: 245-249. 1963.

167) Bryant, M. P., B. F. Barrentine, J. F. Sykes, I. M. Robinson, C. V. Shawver and L. W. Willi AMs, J. Dairy Sci., 43: 1435-1444. 1960.

168） Clarke, R. T. J., Ph. D. Thesis. Massey Univ. 1964.

169) Gutierre $z$, J. and R. E. Dayis, J. Anim. Sci., 21 : 819-823. 1962

170) Kleiber, M., H. H. Cole and S. W. Mead, J. Dairy Sci., 26: 929-933. 1943.

171) Mishra, B. D., E. E. Bartley, L. R. Fina and M. P. Bryant, J. Anim. Sci， 27：1651-1656. 1968.

172) Mishra, B. D., L. R. Fina, E. E. Bartley and T. J. Claydon, J Anim. Sci., 26: 606-612. 1967.

173) FAY, J. P., K. -J. Cheng, M. R. Hanna, R. E. Howarth and J. W. Costerton, Can. J. Microbiol., 27: 390-399. 1981.

174) Fay, J. P., K. -J. Cheng, M. R. Hanna, R. E. Howarth and J. W. Costerton, J. Dairy Sci., 63: 1273-1281. 1980.

175) Gutierrez, J., R. E. Davis and I. L. Lindahl, Appl. Microbiol, 7: 304-308. 1959.

176) Bailey, R. W. and A. E. Oxford, J.Gen. Micro biol., 19: 130-145. 1958.

177) Hobson, P. N. and M. J. MacPherson, Biochem. J., 57: 145-151. 1954.

178) Cheng, K.-J., R. Hironaka, G. A. Jones, T. Nicas and J.W. Costerton, Can. J. Microbiol., 22: 450-459. 1976

179) Hartman, P. S., R. H. Johnson, J. R. Brown, N. L. Jacobson, R. S. Allen, P. R. Shelleneerger and H. H. Van Horn, Iowa State J. Sci., 36: 217-231. 1962.

180) Mishra, B. D., Ph. D. Thesis Kansas State Univ. 1964.

181) Ciarke, R. T. J., Nature, 205:95-96. 1965.

182) Clarke, R. T. J., N. Z. J. Agr. Res., 8: 1-9. 1965.

183) Clarke, R. T. J. and C. S. W. Reid, N. Z. J. Agr. Res., 12: 437-445. 1969.

184) Clarke, R. T. J., C. S. W. Reid and P. W. Younc, N. Z. J. Agr. Res., 12：446-466. 1969. 
185) Prins, R. A. and W. Van Hoven, Protistologia, 13: 549-556. 1977.

186) Van Hoven, W. and R. A. Prins, Protistologia, 13 599-606. 1977.

187) Konras, R., Am. J. Vet. Res., 27: 629-632. 1966.

188) Abou Akkada, A. R. and B. H. Howard, Biochem. J., 76: 445-451. 1960.

189）枷时正跈・星野昼夫，日音会報， 50：1-7. 1979 .

190) Wakita, M. and S. Hoshino, Comp. Biochem. Physiol,, 65B: 571-574, 1980.

191) Shinozaki, K., Tohoku J. Agr. Res., 9: 237-250. 1958.

192) Dougherty, R. W., Comell Vet., 32: 269-280. 1942.

193) Shinozaki, K., Tohoku J. Agr. Res., 8: 149-154. 1957.

194) Vallenas, G. A., Am. J. Vet. Res., 17: 79-89. 1956.

195) Cheng, K. -J., C. B. Batley, R. Hironaka and J. W. Costerton, Can. J. Anim. Sci., 59: 737747. 1979.

196) Hancock, J,, J. Agr. Sci., 45: 80-95. 1954.

197) Johns, A. T., Vet. Res. Annot., 4: 17-31. 1958.

198) Knapp, B., A. L. Baker and R. W. Phillips, J. Anim. Sci. 2: 221-225. 1943.

199) Reid, C. S. W., R. T. J. Clarke, M. P. Gurnsey,
R. E. Hungate and K. L. Macmillan, Proc. N. Z. Soc. Anim. Prod., 32: 96-98. 1972.

200) Miller, K. R. and E. C. Frederick, J. Anim. Sci., 25: 1254, 1966.

201) Jones, W. T., R. B. Broadhurst and M. P. GuriStx, Biochim. Biophys. Acta, 701: 382-388. 1982.

202) Cheng, K. -J., C. B. Bailey, R. Hironaka and M. Kapoor, Can. J. Anim. Sci, 57: 15-21. 1977.

203) Clarke, R. T. J., W. T. Jones, J. W. Lyttleton, J. M. MCARther and C.S.W. Reid, Proc. 11th Int. Grassl. Congr., 777. 1970.

204) Van Horn, H. H. and E. E. Bartley, J. Anim. Sci, 20: 85-87. 1961.

205) Bartley, E. E. and I. S. Yadava, J. Anim. Sci., 20: 648-653. 1961.

206) Horacek, G. L., L. R. Fina, H. S. Tillinghast, R. L. Gettings and E. E. Bartley, Can. J. Microbiol., 23: 100-106. 1977.

207）宇仼川智也・西野武蔵，日畜北陸支部会報，41: 15-19. 1980.

208）宇佐川智也・西野武藏、日窗会報，53：535-540, 1982.

209）中嶋隆文・增野脚也・坂内良二・星野貞太，日音 侌報，53：541-546. 1982 . 